Review

\title{
Maturity onset diabetes of the young: Diagnosis and treatment options
}

\author{
Serghei Covanțev ${ }^{1}$, Andrian Chiriac ${ }^{2}$, Ludmila Perciuleac ${ }^{1}$, Vladlena Zozina \\ ${ }^{1}$ State University of Medicine and Pharmacy „Nicolae Testemițanu”, Chisinau, Republic of Moldova \\ ${ }^{2}$ Mother and Child Institute, Chisinau, Republic of Moldova
}

Received 16 July 2016, Accepted 6 September 2016

(C) 2016, Covanțev S., Chiriac A., Perciuleac L., Zozina V.

(C) 2016, Russian Open Medical Journal

\begin{abstract}
Diabetes is a complicated disease, so multiple factors are involved in its development. Nevertheless some of the patients with type 1 and 2 diabetes mellitus have a monogenic form of this disease which has different treatment options and usually fewer complications. It is estimated that about $5 \%$ of patients with type 2 diabetes melitus (T2DM) and about $10 \%$ of type 1 diabetes melitus (T1DM) are misdiagnosed and have maturity onset diabetes of the young (MODY). We present a review study of the management of most frequent monogenic forms of diabetes such as MODY 1, 2 and 3 and the possibilities of their diagnosis including in resource limited situations.
\end{abstract}

Keywords: HNF-1a, HNF-4a, GCK, monogenic forms of diabetes.

Cite as Covanțev S, Chiriac A, Perciuleac L, Zozina V. Maturity onset diabetes of the young: Diagnosis and treatment options. Russian Open Medical Journal 2016; 5: e0402.

Correspondence to Covanțev Serghei. E-mail: kovantsev.s.d@gmail.com

\section{Introduction}

The number of adults with diabetes steadily rises and is currently described as an "epidemic". It is presumed that between 2010 and 2030, there will be a 69\% increase in numbers of adults with diabetes in developing countries and a $20 \%$ increase in developed countries [1]. By 2030 the number of individuals with diabetes worldwide may rise to 472 million and $80 \%$ of them will be in low and middle income countries. In some of these countries diabetic drugs and insulin are inaccessible or rather expensive and that eventually will affect the whole healthcare system [2]. Diabetes has a high rate of morbidity and mortality due to its complications, among which are vascular complications with high risk of infarction, diabetic foot, stroke, loss of vision and renal dysfunctions which result in end stage kidney disease [3]. In 2000 diabetes mellitus caused 2.9 million deaths, equivalent to $5.2 \%$ of world all-cause mortality. Depending on the country it represents $2-27 \%$ of deaths [4]. By 2010 the numbers had increased and the total number of excess deaths attributable to diabetes worldwide was estimated to be 3.96 million thus representing $6.8 \%$ of global mortality [5]. Still not all of these patients have the classical types of diabetes. Some of them may have monogenic forms with sometimes different presentations and better treatment options if they are diagnosed properly and in time. At least 13 maturity onset diabetes of the young (MODY) subtypes with distinct genetic etiologies have been identified till now. The most frequent types are MODY 1, 2 and 3 which will be furthermore discussed in the article due to their higher prevalence (up to $90 \%$ of all MODY) in the population $[6,7]$.

\section{MODY incidence and prevalence}

The prevalence and incidence of MODY largely depends on the country and there are often new cases MODY diagnosed in the population [8]. The minimum prevalence of MODY was reported to be $1.1-4.2 \%$ of patients with diabetes or $2.4-4.6$ cases per 100,000 [9-16]. In Russian population the frequency of MODY 2 and MODY 3 possibly are the same unlike in other countries [17]. In Turkish population MODY 2 is considered to be the leading cause of MODY [18]. In the other countries the data about MODY is limited since only incidental findings were described till now [19]. In some populations MODY may have a higher incidence particularly if the community tend to maintain ethnic seclusion [20]. The curent statement declares that MODY incidence and prevalence is undreestimated by up to $80-95 \%[11,21]$. Patients with MODY are often misdiagnosed as having other types of diabetes and the lack of knowledge and awareness is still one of the important factors $[22,23]$.

All of the curent data show that MODY is distributed unequally in different countries thus each country should perform its own population studies in order to determine the prevalence of the disease in the population [9-12].

The cost-effectiveness of diagnosing MODY should also be taken in considerations since both health and financial benefits can be found in this situation [24]. 
Table 1. MODY clinical features

\begin{tabular}{|c|c|c|c|}
\hline Criteria & MODY1 & MODY2 & MODY3 \\
\hline Gene, locus & HNF-4a, 20q13.12 & GCK 7, p15.3-p15.1 & HNF-1a, 12q24.31 \\
\hline Age of diagnosis & $15-45$ years & $\begin{array}{l}\text { Present from birth; presents at } \\
\text { any age }\end{array}$ & $15-45$ years \\
\hline Parental history of diabetes & $60-90 \%$ & $\begin{array}{l}\text { One parent usually has impaired } \\
\text { fasting glycaemia }\end{array}$ & $60-90 \%$ \\
\hline Ketoacidosis & Rare, but possible & Rare, but possible & Rare, but possible \\
\hline Insulin secretion & $\begin{array}{l}\text { Defected with clinical } \\
\text { presentation in adolescence or } \\
\text { early adulthood }\end{array}$ & Can be decreased by $60 \%$ & $\begin{array}{l}\text { Defected with clinical presentation in } \\
\text { adolescence or early adulthood }\end{array}$ \\
\hline Insulin resistance & Uncommon & Uncommon & Uncommon \\
\hline Biochemical analysis & $\begin{array}{l}\text { Low HDL, high LDL, normal C- } \\
\text { peptide concentrations }\end{array}$ & $\begin{array}{l}\text { Low free fatty acids and } \\
\text { triglycerides }\end{array}$ & $\begin{array}{l}\text { low hsCRP, high HDL, normal C-peptide } \\
\text { concentrations }\end{array}$ \\
\hline$\beta$-cell antibodies & Rare (less than $1 \%$ ) & Rare (less than $1 \%$ ) & Rare (less than $1 \%$ ) \\
\hline Vascular complications & Frequent & Rare & Frequent \\
\hline Renal threshold for glucose & Normal & Can be low (glycosuria) & Low (glycosuria) \\
\hline
\end{tabular}

\section{MODY features and diagnosis}

The genetic defects mostly affect $\beta$-cells of the pancreas and liver. These mutations cause a condition similar to type 2 diabetes mellitus (T2DM) and have no autoimmune etiology. The disease onset is usually before the age of 25 . The patients are usually not overweight and respond to conservative treatment with sulfonylureas and a proper diet [6].

These mutations are characterized by high level of penetrance thus $95 \%$ of individuals that have MODY will become diabetic or will have an altered glucose metabolism before the age of 55 [25]. Misdiagnosis of MODY is a widespread problem and about $5 \%$ of patients with T2DM and about 10\% type 1 diabetes melitus (T1DM) actually may have MODY [25]. For instance in one study 20 of 247 patients clinically labeled as T1DM actually had hepatocyte nuclear factor 1a (HNF-1a) or HNF-4a mutations. From 322 patients clinically labeled as T2DM 80 had HNF-1a or HNF-4a mutations and 40 had glucokinase (GCK) mutation [26].

Patients with MODY usually have several clinical features: strong indications of diabetes inheritance in the family, early onset of the disease, relative insulin independence, absence of insulin resistance and $\beta$-cells autoimmunity (Table 1 ) [27].

Patients who have two or more family members with diabetes may have MODY in up to $45 \%$ of cases [28].

T1DM is characterized by the presence of islet autoantibodies, such as glutamate decarboxylase (GAD) and islet antigen-2 (IA-2) antibodies but they may be present in less than $1 \%$ of patients with MODY [29]. Thus antibodies are an effective tool in diagnosing MODY but rarely a combination of monogenic forms with T1DM may exist [30, 31]

Still the most exact diagnostic procedure that can be performed is genetic testing which is a gold standard when it comes to monogenic diseases [32]. Haplotypes may also have a significant impact when diagnosing MODY since T1DM usually is associated with specific human leukocyte antigens $[33,34]$.

Since some countries have no or limited access to genetic testing other data should be taken in consideration:

- diabetes diagnosed before 45 years,

- negative diabetes autoantibodies (GADA, IA-2, zinc transporter ZnT8, and insulin autoantibodies (IAA)),
- no insulin resistance,

- family history of diabetes,

- detectable C-peptide more than $0.2 \mathrm{nmol} / \mathrm{l}$ outside the honeymoon period, GST more than $0.2 \mathrm{nmol} / \mathrm{I}[22,27]$,

- Presence of liver pathology particularly both benign and malignant primary liver cell tumors (liver adenomatosis, hepatocellular carcinoma) [35-40].

During pregnancy body mass index (BMI) $<25 \mathrm{~kg} / \mathrm{m}^{2}$ and fasting glucose $\geq 5.5 \mathrm{mmol} / \mathrm{L}$ can also be used as separate indicators of GCK mutation and has a sensitivity of $68 \%$ and $96 \%$ specificity. A study that involved the Atlantic Diabetes in Pregnancy cohort showed that 1.1 out of 1,000 pregnant women had GCK mutation [41]. Other studies showed that in $3 \%$ of cases GCK mutation is the cause of gestational diabetes [42].

Urinary C-peptide creatinine ratio is another test that can help to distinguish MODY from T1DM, but does not show a great distinction between MODY and T2DM. The UCPCR is $<0.03-0.39$ $\mathrm{nmol} / \mathrm{mmol}$ for T1DM and is $2.37-5.32 \mathrm{nmol} / \mathrm{mmol}$ for MODY [43]. This test was reported to have sensitivity up to $93 \%$ and specificity up to $90 \%$ for discriminating between MODY and T1DM. [44]

\section{MODY 1}

HNF-4a regulates transcription of the insulin gene and other genes that are involved in glucose metabolism. If HNF-4a function is decreased then it affects the b-cells mainly by controlling HNF1a which is also a transcription factor for insulin. Mutation in HNF4a causes MODY 1 with altered response of insulin secretion in case of high glucose levels. Mutations in HNF-4a sometimes can cause neonatal hyperinsulinemic hypoglycemia and in $50 \%$ of cases macrosomia. Some gastrointestinal dysfunctions can also be present due to the fact that recent data links this transcription factor with intestinal homeostasis [27, 45, 46]. Glycosuria is not present in HNF-4a MODY, and low levels of apolipoproteins (apoA11, apoCIII, and apoB) can be a diagnostic clue in this case [47]. In some patients it is possible to switch insulin therapy to more appropriate drugs. Bazalova and coworkers reports that one patient remained on insulin therapy after 27 years of treatment due to severe complications, another one that had diabetes for 48 years was switched to a more suitable therapy which can be due to different levels of compensation of diabetes [48]. 


\section{MODY 2}

The GCK gene is located on 7th human chromosome p15.3p15.1, consists of 10 exons and encodes a 456 amino-acid protein. GCK acts as a glucose sensor enzyme in the b-cells of the pancreas and in liver cells besides that it also phosphorylates glucose. By phosphorylating glucose into glucose-6-phosphate it begins the process of glucose storage or glycolysis. First GCK mutation was reported in 1992 and since then there have been described approximately 200 different mutations [46, 49].

GCK is considered to be the most stable mutation from all MODY but due to loss of sensory function of $\beta$-cells insulin secretion rate can be decreased by $60 \%$ [50]. MODY 2 is characterized as non-progressive and complications free metabolic disease probably due to lower levels of free fatty acids and triglycerides [51]. In one of the studies it was shown that children with asymptomatic hyperglycemia frequently have MODY 2 and their mothers in $5-80 \%$ of cases had gestational diabetes [45].

Bazalova and coworkers report that son and father with GCK mutation that were previously on diabetic treatment successfully started diet treatment without any medication. The uncle on the other hand remained on combined oral diabetic drugs. This underlines the importance of early diagnosis of the disease [48].

Among the other methods to identify candidate patients for MODY2 genetic testing a group of authors developed a diagnostic flowchart in order to improve the detection rate and to increase the number of properly requested tests. The flowchart is called 7if and consists of 7 binary "yes or no" questions. The 7-iF, in a prospective 2-year study (921 diabetic children) showed a precision of about the $76 \%$. Also using retrospective data, the 7-iF showed a precision in identifying MODY2 patients of about $80 \%$ [52].

\section{MODY 3}

HNF-1a codes for the transcription factor HNF-1 $\alpha$, which interacts with deoxyribonucleic acid (DNA) as a homodimer or a heterodimer with HNF-1 $\beta$, to regulate multiple cellular functions including glucidic metabolism, lipidic transport, and detoxication [35]. In case of HNF-1a mutations patients develop diabetes by the age of 25 in $63 \%$ and by the age of 50 in $94 \%$ of cases [46]. Several environmental and genetic factors are known to modify the age at HNF1a-MODY diagnosis, particularly intrauterine hyperglycemia and HNF-1a mutation position [53, 54]. Furthermore females are usually diagnosed earlier [53].

Patients usually have normal or even higher insulin sensitivity but their pancreatic endocrine function is directly altered and requires treatment. The condition may also be associated with hepatic adenomatosis, bile acid synthesis alteration, decreased pancreatic volume, pancreatic dysfunction and other diseases [37, $38,55-58]$. The patients also have elevated urinary glucose due to low renal threshold for glucose in this genetic subtype [59].

Several other markers may serve as a diagnostic tool such as altered glucose fucosilation of $\mathrm{N}$-linked glycans on plasma proteins [6]. Serum high-sensitivity C-reactive protein (hsCRP) levels are lower in HNF-1a MODY than in other forms of diabetes. The specificity of hsCRP test is $80 \%$ and it is considered to be an easily available biomarker $[60,61]$. Other test may also be useful. For instance serum 1,5 -anhydroglucitol $(1,5 \mathrm{AG})$ performed well in discriminating GCK-MODY from other diabetes subtypes, particularly HNF1A-MODY. Mean (SD range) 1,5AG levels were:
GCK-MODY $13.06 \mathrm{microg} / \mathrm{ml}$ (5.74-29.74), HNF1A-MODY 4.23 $\mathrm{microg} / \mathrm{ml}$ (2.12-8.44), type 1 diabetes 3.09 microg/ml (1.45-6.57), LADA $3.46 \mathrm{microg} / \mathrm{ml}$ (1.42-8.45), and type 2 diabetes 5.43 (2.1213.23) [62]. The receiver operating characteristic (ROC) curve analysis revealed $85.7 \%$ sensitivity and $80.0 \%$ specificity of $1,5 \mathrm{AG}$ in screening for HNF-1 $\alpha$ MODY at the criterion of $<6.5 \mu \mathrm{g} / \mathrm{ml}$ in patients with an A1C level between 6.5 and 9.0\% [63].

It is important to mention that mutation in both GCK and HNF1a presents as a MODY 3 probably due to the leading role of transcription factor HNF-1a in the disease [64].

\section{MODY management}

GCK mutation usually causes a mild, asymptomatic hyperglycemia. No treatment is needed for this group of patients but they should be monitored. Early diagnosis of this disease is essential for stopping the insulin therapy in time [65]. But it is important to mention that the managment of pregnant women with GCK mutations is harder than those with HNF-1a mutations. An increased percentage of miscarriages in GCK pregnancies should also be considered. Since there is limited data on this subject current insulin protocols should be implemented in MODY diabetes patients who are pregnant [66].

HNF-1a and HNF-4a mutations cause more prominent hyperglycemias and with time vascular complications. The optimal treatment options in these conditions are sulfonylureas drugs. The patient should be monitored carefully since the disease is not always stable and additional lines of therapy may be helpful in future [67]. Still it is considered that approximately $70-80 \%$ of patients can successfully be treated with sulfonylureas with no insulin injections $[46,48,68]$. Some patients on the other hand remain on insulin treatment due to complications [48]. Demol and coworkers report a case where treatment with sulfonylurea was found to be a clinically ineffective alternative to insulin therapy due to a particular mutation type in HNF-1a [69].

In one of the studies 60 patients with HNF1A-MODY were matched with 60 BMI-, age-, ethnicity- and diabetes durationmatched patients with T1DM. After 84 month follow-up the majority of the cohort treated with sulfonylurea therapy remained insulin independent at 84-month follow-up (80\%). The HbA1c in the HNF1a-MODY group treated with sulfonylurea therapy alone improved significantly over the study period. The rate of retinopathy was significantly lower in the HNF1a-MODY group than that in the T1DM group as well as a lower rate of microalbuminuria and cardiovascular disease [68].

Other medications can also be useful, for instance glucagonlike peptide-1 receptor agonists, dipeptidyl peptidase IV inhibitors, meglitinide analogues showed excellent results in controlling glucose levels as well [70-73].

The presence of monogenic diabetes does not give protection from having metabolic syndrome or elements of T2DM and patients with some of the genetic variations are more likely to develop these metabolic diseases over time [74, 75]. There are also rare reports of patients with MODY who later developed T1DM [30, 31].

Macrovascular risk factors are more frequent in T2DM still 23\% of MODY patients may have dyslipidemia and $10 \%$ hypertension [76]. Liver and pancreatic functions should be carefully monitored in MODY $3[37,38,55-58]$. 
The data involving MODY patients and surgical outcomes is limited and currently mostly involves transplantation surgery outcomes. Simultaneous pancreas and kidney transplantation in MODY is discussed in several articles with good postoperative results $[77,78]$.

The implementation of registry for monogenic diabetes should also be a helpful tool since it provides data about the incidence rates and clinical presentation of diabetes in a particular population $[79,80]$. It also has low cost and allows collecting a wide range of longitudinal data on rare patients from diverse geographic locations [81].

\section{Conclusion}

In the last decade there is growing attention toward monogenic forms of diabetes and their frequency in the population may be higher than it was firstly presumed. Careful study of the patient's family history and more accurate laboratory testing may be useful to find patients with MODY. Still the best method for any monogenic disease remains genetic testing but due to limited financial support in some countries alternative methods can be successfully used for MODY screening. Further investigation in this area can improve the possibilities for diagnosis and treatment of genetic diabetes, its complications and improve the quality of life and life expectancy.

\section{Conflict of interest}

The authors declare that they have no conflict of interest.

\section{References}

1. Shaw JE, Sicree RA, Zimmet PZ. Global estimates of the prevalence of diabetes for 2010 and 2030. Diabetes Res Clin Pract 2010; 87(1): 4-14. PMID: 19896746. DOI: 10.1016/j.diabres.2009.10.007.

2. The diabetes pandemic. Lancet 2011; 378(9786): 99. PMID: 21742159. DOI: 10.1016/s0140-6736(11)61068-4.

3. Advances and emerging opportunities in diabetes research: a strategic planning report of the Diabetes Mellitus Interagency Coordinating Committee. National Institute of Diabetes and Digestive and Kidney Diseases (Ed.). Bethesda, MD, National Institutes of Health, (NIH publ. no. 11-7572), 2011.

4. Roglic G, Unwin N, Bennett PH, Mathers C, Tuomilehto J, Nag S, et al. The burden of mortality attributable to diabetes: realistic estimates for the year 2000. Diabetes Care 2005; 28(9): 2130-2135. PMID: 16123478. DOI: 10.2337/diacare.28.9.2130

5. Roglic G, Unwin N. Mortality attributable to diabetes: estimates for the year 2010. Diabetes Res Clin Pract 2010; 87(1): 15-19. PMID: 19914728. DOI: 10.1016/j.diabres.2009.10.006.

6. Thanabalasingham G, Huffman JE, Kattla JJ, Novokmet M, Rudan I, Gloyn AL, et al. Mutations in HNF1A result in marked alterations of plasma glycan profile. Diabetes 2013; 62(4): 1329-1337. PMID: 23274891. DOI: $10.2337 / \mathrm{db} 12-0880$.

7. Estalella I, Rica I, Perez de Nanclares G, Bilbao JR, Vazquez JA, San Pedro Jl, et al. Mutations in GCK and HNF-1alpha explain the majority of cases with clinical diagnosis of MODY in Spain. Clin Endocrinol 2007; 67(4): 538-546. PMID: 17573900. DOI: 10.1111/j.13652265.2007.02921.x.

8. Pruhova S, Ek J, Lebl J, Sumnik Z, Saudek F, Andel M, et al. Genetic epidemiology of MODY in the Czech republic: new mutations in the MODY genes HNF-4alpha, GCK and HNF-1alpha. Diabetologia 2003; 46(2): 291-295. PMID: 12627330. DOI: 10.1007/s00125-002-1010-7.

9. Irgens $\mathrm{HU}$, Molnes J, Johansson BB, Ringdal M, Skrivarhaug $\mathrm{T}$, Undlien $\mathrm{DE}$, et al. Prevalence of monogenic diabetes in the population-based
Norwegian Childhood Diabetes Registry. Diabetologia 2013; 56(7): 1512-1519. PMID: 23624530. DOI: 10.1007/s00125-013-2916-y.

10. Wheeler B, Patterson N, Love D, Prosser D, Tomlinson P, Taylor BJ, Manning $P$. Frequency and genetic spectrum of maturity-onset diabetes of the young (MODY) in southern New Zealand. Journal of Diabetes \& Metabolic Disorders 2013; 12(1): 46. PMID: 24355479. DOI: 10.1186/2251-6581-12-46.

11. Shields BM, Hicks S, Shepherd MH, Colclough K, Hattersley AT, Ellard S. Maturity-onset diabetes of the young (MODY): how many cases are we missing? Diabetologia 2010; 53(12): 2504-2508. PMID: 20499044. DOI: 10.1007/s00125-010-1799-4.

12. Weinreich SS, Bosma A, Henneman L, Rigter T, Spruijt CM, Grimbergen $\mathrm{AJ}$, et al. A decade of molecular genetic testing for MODY: a retrospective study of utilization in The Netherlands. Eur J Hum Genet 2015; 23(1): 29-33. PMID: 24736738. DOI: 10.1038/ejhg.2014.59.

13. Fendler W, Borowiec M, Baranowska-Jazwiecka A, Szadkowska A, Skala-Zamorowska E, Deja G, et al. Prevalence of monogenic diabetes amongst Polish children after a nationwide genetic screening campaign. Diabetologia 2012; 55(10): 2631-2635. PMID: 22782286. DOI: 10.1007/s00125-012-2621-2.

14. Mozzillo E, Salzano G, Barbetti F, Maffeis C, Lombardo F, Franzese A, et al. Survey on etiological diagnosis of diabetes in 1244 Italian diabetic children and adolescents: impact of access to genetic testing. Diabetes Res Clin Pract 2015; 107(3): e15-e18. PMID: 25649912. DOI: 10.1016/j.diabres.2015.01.003.

15. Neu A, Feldhahn L, Ehehalt S, Hub R, Ranke MB. Type 2 diabetes mellitus in children and adolescents is still a rare disease in Germany: a population-based assessment of the prevalence of type 2 diabetes and MODY in patients aged 0-20 years. Pediatr Diabetes 2009; 10(7): 468473. PMID: 19496965. DOI: 10.1111/j.1399-5448.2009.00528.x.

16. Valentínová L, Beer NL, Staník J, Tribble ND, van de Bunt M, Hučková $M$, et al. Identification and functional characterisation of novel glucokinase mutations causing maturity-onset diabetes of the young in Slovakia. PLoS ONE 2012; 7(4): e34541. PMID: 22493702. DOI: 10.1371/journal.pone.0034541.

17. Peterkova V, Kuraeva T, Prokofiev S, Emel'ianov AO, Zakharova Elu, Tsygankova PG, Grishina DP. Molecular genetics and clinical aspects of monogenic diabetes mellitus. Vestn Akad Med Nauk 2012; (1): 81-86. PMID: 22550716

18. Anik A, Catli G, Abaci A, Sarı E, Yeşilkaya E, Korkmaz HA, et al. Molecular diagnosis of maturity-onset diabetes of the young (MODY) in Turkish children by using targeted next-generation sequencing. J Pediatr Endocrinol Metab 2015; 28(11-12): 1265-1271. PMID: 26226118. DOI: 10.1515/jpem-2014-0430.

19. Covanțev S, Chiriac A, Perciuleac L. A case of maturity onset diabetes of the young. Arta Medica - Ediție specială Congresul Național al Societății Endocrinologilor din Republica Moldova 2014; 53(2): 84. DOI: 10.13140/RG.2.1.3424.3047.

20. Gozlan Y, Tenenbaum A, Shalitin S, Lebenthal Y, Oron T, Cohen O, et al. The glucokinase mutation p.T206P is common among MODY patients of Jewish Ashkenazi descent. Pediatr Diabetes 2012; 13(6): e14-e21. PMID: 21978167. DOI: 10.1111/j.1399-5448.2011.00822.x.

21. Kleinberger JW, Pollin TI. Undiagnosed MODY: Time for action. Curr Diab Rep 2015; 15(12): 110. PMID: 26458381. DOI: 10.1007/s11892015-0681-7.

22. Chambers C, Fouts A, Dong F, Colclough K, Wang Z, Batish SD, et al. Characteristics of maturity onset diabetes of the young in a large diabetes center. Pediatr Diabetes 2016; 17(5): 360-367. PMID: 26059258. DOI: 10.1111/pedi.12289.

23. van der Zwaag AM, Weinreich SS, Bosma AR, Rigter T, Losekoot M, Henneman L, Cornel MC. Current and best practices of genetic testing for maturity onset diabetes of the young: views of professional experts. Public Health Genomics 2015; 18(1): 52-59. PMID: 25341961. DOI: $10.1159 / 000367963$. 
24. Schnyder S, Mullis PE, Ellard S, Hattersley AT, Fluck CE. Genetic testing for glucokinase mutations in clinically selected patients with MODY: a worthwhile investment. Swiss Med Wkly 2005; 135(23-24): 352-356. PMID: 16059790. DOI: 2005/23/smw-11030.

25. Oliveira CSV, Furuzawa GK, Reis AF. Diabetes mellitus do tipo MODY. Arquivos Brasileiros de Endocrinologia \& Metabologia 2002; 46: 186192. DOI: 10.1590/S0004-27302002000200012.

26. Thanabalasingham G, Pal A, Selwood MP, Dudley C, Fisher K, Bingley $\mathrm{PJ}$, et al. Systematic assessment of etiology in adults with a clinical diagnosis of young-onset type 2 diabetes is a successful strategy for identifying maturity-onset diabetes of the young. Diabetes Care 2012; 35(6): 1206-1212. PMID: 22432108. DOI: 10.2337/dc11-1243.

27. Thanabalasingham G, Owen KR. Diagnosis and management of maturity onset diabetes of the young (MODY). BMJ 2011; 343: d6044. PMID: 22012810. DOI: 10.1136/bmj.d6044.

28. Petruzelkova L, Dusatkova P, Cinek O, Sumnik Z, Pruhova S, Hradsky O, et al. Substantial proportion of MODY among multiplex families participating in a Type 1 diabetes prediction programme. Diabet Med 2015 Dec 7. [Epub ahead of print] PMID: 26641800. DOI: 10.1111/dme.13043.

29. McDonald TJ, Colclough K, Brown R, Shields B, Shepherd M, Bingley P, et al. Islet autoantibodies can discriminate maturity-onset diabetes of the young (MODY) from Type 1 diabetes. Diabet Med 2011; 28(9): 1028-1033. PMID: 21395678. DOI: 10.1111/j.1464-5491.2011.03287.x.

30. Bowden SA, Hoffman RP. Triple diabetes: coexistence of type 1 diabetes mellitus and a novel mutation in the gene responsible for MODY3 in an overweight adolescent. Pediatr Diabetes 2008; 9(2): 162164. PMID: 18221440. DOI: 10.1111/j.1399-5448.2007.00335.x.

31. Maltoni G, Zucchini S, Scipione M, Mantovani V, Salardi S, Cicognani A. Onset of type 1 diabetes mellitus in two patients with maturity onset diabetes of the young. Pediatr Diabetes 2012; 13(2): 208-212. PMID: 21696527. DOI: 10.1111/j.1399-5448.2011.00788.x.

32. Bennett JT, Vasta V, Zhang M, Narayanan J, Gerrits P, Hahn SH. Molecular genetic testing of patients with monogenic diabetes and hyperinsulinism. Mol Genet Metab 2015; 114(3): 451-458. PMID: 25555642. DOI: 10.1016/j.ymgme.2014.12.304.

33. Noble JA, Valdes AM. Genetics of the HLA region in the prediction of type 1 diabetes. Curr Diab Rep 2011; 11(6): 533-542. PMID: 21912932. DOI: $10.1007 / \mathrm{s} 11892-011-0223-x$.

34. Bugawan TL, Klitz W, Alejandrino M, Ching J, Panelo A, Solfelix CM, et al. The association of specific HLA class I and II alleles with type 1 diabetes among Filipinos. Tissue Antigens 2002; 59(6): 452-469. PMID: 12445315. DOI: 10.1034/j.1399-0039.2002.590602.x.

35. Willson JS, Godwin TD, Wiggins GA, Guilford PJ, McCall JL. Primary hepatocellular neoplasms in a MODY3 family with a novel HNF1A germline mutation. Journal of hepatology 2013; 59(4): 904-907. PMID: 23707370. DOI: 10.1016/j.jhep.2013.05.024.

36. Hirata E, Shimizu S, Umeda S, Kobayashi T, Nakano M, Higuchi H, et al. Hepatocyte nuclear factor 1alpha-inactivated hepatocellular adenomatosis in a patient with maturity-onset diabetes of the young type 3: case report and literature review. Nihon Shokakibyo Gakkai zasshi = The Japanese journal of gastro-enterology 2015; 112(9): 16961704. PMID: 26346360. DOI: 10.11405/nisshoshi.112.1696.

37. Ekholm E, Nilsson R, Groop L, Pramfalk C. Alterations in bile acid synthesis in carriers of hepatocyte nuclear factor 1alpha mutations. J Intern Med 2013; 274(3): 263-272. PMID: 23607861. DOI: 10.1111/joim.12082.

38. Iwen KA, Klein J, Hubold C, Lehnert H, Weitzel JM. Maturity-onset diabetes of the young and hepatic adenomatosis - characterisation of a new mutation. Exp Clin Endocrinol Diabetes 2013; 121(6): 368-371. PMID: 23616187. DOI: 10.1055/s-0033-1341519.

39. Stueck AE, Qu Z, Huang MA, Campreciós G, Ferrell LD, Thung SN. Hepatocellular carcinoma arising in an HNF-1alpha-mutated adenoma in a 23-year-old woman with maturity-onset diabetes of the young: a case report. Seminars in Liver Disease 2015; 35(4): 444-449. PMID: 26676820. DOI: 10.1055/s-0035-1567827.

40. Bacq $Y$, Jacquemin E, Balabaud C, Jeannot E, Scotto B, Branchereau S, et al. Familial liver adenomatosis associated with hepatocyte nuclear factor 1alpha inactivation. Gastroenterology 2003; 125(5): 1470-1475. PMID: 14598263. DOI: 10.1016/j.gastro.2003.07.012.

41. Chakera AJ, Spyer G, Vincent N, Ellard S, Hattersley AT, Dunne FP. The $0.1 \%$ of the population with glucokinase monogenic diabetes can be recognized by clinical characteristics in pregnancy: the Atlantic Diabetes in Pregnancy cohort. Diabetes Care 2014; 37(5): 1230-1236. PMID: 24550216. DOI: 10.2337/dc13-2248.

42. Haladova I, Cechurova D, Lacigova S, Rusavy Z. Monogenic glucokinase diabetes and pregnancy: a case study. Wiener klinische Wochenschrift 2015; 127(11-12): 494-496. PMID: 25986997. DOI: 10.1007/s00508015-0795-6.

43. Besser RE, Shields BM, Hammersley SE, Colclough K, McDonald TJ, Gray $Z$, et al. Home urine C-peptide creatinine ratio (UCPCR) testing can identify type 2 and MODY in pediatric diabetes. Pediatr Diabetes 2013; 14(3): 181-188. PMID: 23289766. DOI: 10.1111/pedi.12008.

44. Yilmaz Agladioglu S, Sagsak E, Aycan Z. Urinary C-peptide/creatinine ratio can distinguish maturity-onset diabetes of the young from type 1 diabetes in children and adolescents: a single-center experience. Horm Res Paediatr 2015; 84(1): 54-61. PMID: 25792383. DOI: 10.1159/000375410.

45. Aguilar-Salinas CA, Reyes-Rodríguez E, Ordóñez-Sánchez ML, Torres MA, Ramírez-Jiménez S, Domínguez-López A, et al. Early-onset type 2 diabetes: metabolic and genetic characterization in the Mexican population. The Journal of Clinical Endocrinology \& Metabolism 2001; 86(1): 220-226. PMID: 11232004. DOI: doi:10.1210/jcem.86.1.7134.

46. Naylor R, Philipson LH. Who should have genetic testing for maturityonset diabetes of the young? Clinical Endocrinology 2011; 75(4): 422 426. PMID: 21521318. DOI: 10.1111/j.1365-2265.2011.04049.x.

47. Lehto M, Bitzen PO, Isomaa B, Wipemo C, Wessman Y, Forsblom C, et al. Mutation in the HNF-4alpha gene affects insulin secretion and triglyceride metabolism. Diabetes 1999; 48(2): 423-425. PMID: 10334325. DOI: 10.2337/diabetes.48.2.423.

48. Bazalová Z, Rypácková B, Broz J, Brunerová L, Polák J, Rusavý Z, et al. Three novel mutations in MODY and its phenotype in three different Czech families. Diabetes Research and Clinical Practice 2010; 88(2): 132-138. PMID: 20132997. DOI:10.1016/j.diabres.2010.01.005.

49. Mota AJ, Bruggemann S, Costa FF. MODY 2: mutation identification and molecular ancestry in a Brazilian family. Gene 2013; 512(2): 486491. PMID: 23085272. DOI: 10.1016/j.gene.2012.10.013.

50. Lane JT. Animal model of human maturity onset diabetes of the young-type 2: similar but different? Transl Res 2011; 157(3): 109-110. DOI: 10.1016/j.trsl.2010.12.006.

51. Spegel P, Ekholm E, Tuomi T, Groop L, Mulder H, Filipsson K. Metabolite profiling reveals normal metabolic control in carriers of mutations in the glucokinase gene (MODY2). Diabetes 2013; 62(2): 653-661. PMID: 23139355. DOI: 10.2337/db12-0827.

52. Pinelli M, Acquaviva F, Barbetti F, Caredda E, Cocozza S, Delvecchio M, et al. Identification of candidate children for maturity-onset diabetes of the young type 2 (MODY2) gene testing: a seven-item clinical flowchart (7-iF). PLoS One 2013; 8(11): e79933. PMID: 24244580. DOI: 10.1371/journal.pone.0079933.

53. Lango Allen H, Johansson S, Ellard S, Shields B, Hertel JK, Raeder H, et al. Polygenic risk variants for type 2 diabetes susceptibility modify age at diagnosis in monogenic HNF1A diabetes. Diabetes 2010; 59(1): 266 271. PMID: 19794065. DOI: 10.2337/db09-0555.

54. Bellanne-Chantelot C, Carette C, Riveline JP, Valéro R, Gautier JF, Larger $E$, et al. The type and the position of HNF1A mutation modulate age at diagnosis of diabetes in patients with maturity-onset diabetes of the young (MODY)-3. Diabetes 2008; 57(2): 503-508. PMID: 18003757. DOI: $10.2337 / \mathrm{db07-0859.}$ 
55. Verhoeven WM, Egger JI, van den Bergh JP, van Beek R, Kleefstra T, de Leeuw N. A 12q24.31 interstitial deletion in an adult male with MODY3: neuropsychiatric and neuropsychological characteristics. Am J Med Genet A 2015; 167A(1): 169-173. PMID: 25425063. DOI: 10.1002/ajmg.a.36730

56. Vesterhus M, Haldorsen IS, Raeder H, Molven A, Njolstad PR. Reduced pancreatic volume in hepatocyte nuclear factor 1A-maturity-onset diabetes of the young. J Clin Endocrinol Metab 2008; 93(9): 3505-3509. PMID: 18593771. DOI: 10.1210/jc.2008-0340.

57. Vesterhus $M$, Raeder $H$, Johansson $S$, Molven A, Njolstad PR. Pancreatic exocrine dysfunction in maturity-onset diabetes of the young type 3. Diabetes Care 2008; 31(2): 306-310. PMID: 17989309. DOI: $10.2337 / \mathrm{dc07}-1002$.

58. Nakamura A, Ishidu K, Tajima T. Early onset of liver steatosis in a Japanese girl with maturity-onset diabetes of the young type 3 (MODY3). J Clin Res Pediatr Endocrinol 2012; 4(2): 104-106. PMID: 22672869. DOI: 10.4274/jcrpe.584.

59. Gloyn AL, Faber JH, Malmodin D, Thanabalasingham G, Lam F, Ueland PM, et al. Metabolic profiling in Maturity-onset diabetes of the young (MODY) and young onset type 2 diabetes fails to detect robust urinary biomarkers. PLoS One 2012; 7(7): e40962. PMID: 22859960. DOI: 10.1371/journal.pone.0040962.

60. Owen KR, Thanabalasingham G, James TJ, Karpe F, Farmer AJ, McCarthy MI, Gloyn AL. Assessment of high-sensitivity C-reactive protein levels as diagnostic discriminator of maturity-onset diabetes of the young due to HNF1A mutations. Diabetes Care 2010; 33(9): 19191924. PMID: 20724646. DOI: $10.2337 /$ dc10-0288.

61. Thanabalasingham $G$, Shah $N$, Vaxillaire $M$, Hansen $T$, Tuomi $T$, Gašperíková $D$ et al. A large multi-centre European study validates high-sensitivity C-reactive protein (hSCRP) as a clinical biomarker for the diagnosis of diabetes subtypes. Diabetologia 2011; 54(11): 28012810. PMID: 21814873. DOI: 10.1007/s00125-011-2261-y.

62. Pal A, Farmer AJ, Dudley C, Selwood MP, Barrow BA, Klyne R, et al. Evaluation of serum 1,5 anhydroglucitol levels as a clinical test to differentiate subtypes of diabetes. Diabetes Care 2010; 33(2): 252-257. PMID: 19933992. DOI: 10.2337/dc09-1246.

63. Skupien J, Gorczynska-Kosiorz S, Klupa T, Wanic K, Button EA, Sieradzki J, Malecki MT. Clinical application of 1,5-anhydroglucitol measurements in patients with hepatocyte nuclear factor-1 $\alpha$ maturityonset diabetes of the young. Diabetes Care 2008; 31(8): 1496-1501. PMID: 1849294. DOI: 10.2337/dc07-2334.

64. Lopez-Garrido MP, Herranz-Antolin S, Alija-Merillas MJ, Giralt P, Escribano J. Co-inheritance of HNF1a and GCK mutations in a family with maturity-onset diabetes of the young (MODY): implications for genetic testing. Clin Endocrinol 2013; 79(3): 342-347. PMID: 23009393. DOI: $10.1111 /$ cen.12050.

65. Codner E, Rocha A, Deng L, Martínez-Aguayo A, Godoy C, Mericq V, Chung WK. Mild fasting hyperglycemia in children: high rate of glucokinase mutations and some risk of developing type 1 diabetes mellitus. Pediatr Diabetes 2009; 10(6): 382-388. PMID: 19309449. DOI: 10.1111/j.1399-5448.2009.00499.x.

66. Bacon S, Schmid J, McCarthy A, Edwards J, Fleming A, Kinsley B, et al. The clinical management of hyperglycemia in pregnancy complicated by maturity-onset diabetes of the young. Am J Obstet Gynecol 2015; 213(2): 236.e1-7. PMID: 25935773. DOI: 10.1016/j.ajog.2015.04.037.

67. Pearson ER, Liddell WG, Shepherd M, Corrall RJ, Hattersley AT. Sensitivity to sulphonylureas in patients with hepatocyte nuclear factor-1alpha gene mutations: evidence for pharmacogenetics in diabetes. Diabet Med 2000; 17(7): 543-545. PMID: 10972586. DOI: 10.1046/j.1464-5491.2000.00305.x

68. Bacon S, Kyithar MP, Rizvi SR, Donnelly E, McCarthy A, Burke M, et al. Successful maintenance on sulfonylurea therapy and low diabetes complication rates in a HNF1A-MODY cohort. Diabet Med 2016; 33(7): 976-984. PMID: 26479152. DOI: 10.1111/dme.12992.

69. Demol S, Lebenthal Y, Bar-Meisels M, Phillip M, Gat-Yablonski G, Gozlan Y. A family with a novel termination mutation in hepatic nuclear factor 1alpha in maturity-onset diabetes of the young type 3 which is unresponsive to sulphonylurea therapy. Horm Res Paediatr 2014; 81(4): 280-284. PMID: 24642958. DOI: 10.1159/000356925.

70. Becker M, Galler A, Raile K. Meglitinide analogues in adolescent patients with HNF1A-MODY (MODY 3). Pediatrics 2014; 133(3): e775e779. PMID: 24567025. DOI: 10.1542/peds.2012-2537

71. Urakami T, Habu M, Okuno M, Suzuki J, Takahashi S, Yorifuji T. Three years of liraglutide treatment offers continuously optimal glycemic control in a pediatric patient with maturity-onset diabetes of the young type 3. J Pediatr Endocrinol Metab 2015; 28(3-4): 327-331. PMID: 25332292. DOI: 10.1515/jpem-2014-0211.

72. Ostoft SH, Bagger JI, Hansen T, Pedersen O, Faber J, Holst JJ, et al. Glucose-lowering effects and low risk of hypoglycemia in patients with maturity-onset diabetes of the young when treated with a GLP-1 receptor agonist: a double-blind, randomized, crossover trial. Diabetes Care 2014; 37(7): 1797-1805. PMID: 24929431. DOI: 10.2337/dc133007.

73. Katra B, Klupa T, Skupien J, Szopa M, Nowak N, Borowiec M, et al. Dipeptidyl peptidase-IV inhibitors are efficient adjunct therapy in HNF1A maturity-onset diabetes of the young patients--report of two cases. Diabetes Technol Ther 2010; 12(4): 313-316. PMID: 20210571. DOI: 10.1089/dia.2009.0159.

74. Stanik J, Kusekova M, Huckova M, Valentinova L, Masindova I, Stanikova $D$, et al. Impact of type 2 diabetes on glucokinase diabetes (GCK-MODY) phenotype in a Roma (Gypsy) family - case report. Endocr Regul 2012; 46(2): 99-105. PMID: 22540858.

75. Holmkvist J, Almgren P, Lyssenko V, Lindgren CM, Eriksson KF, Isomaa $B$, et al. Common variants in maturity-onset diabetes of the young genes and future risk of type 2 diabetes. Diabetes 2008; 57(6): 17381744. PMID: 18332101. DOI: 10.2337/db06-1464.

76. Schober E, Rami B, Grabert M, Thon A, Kapellen T, Reinehr T, et al. Phenotypical aspects of maturity-onset diabetes of the young (MODY diabetes) in comparison with Type 2 diabetes mellitus (T2DM) in children and adolescents: experience from a large multicentre database. Diabet Med 2009; 26(5): 466-473. PMID: 19646184. DOI: 10.1111/j.1464-5491.2009.02720.x.

77. Saudek F, Pruhova S, Boucek P, Lebl J, Adamec M, Ek J, Pedersen O, Hansen T. Maturity-onset diabetes of the young with end-stage nephropathy: a new indication for simultaneous pancreas and kidney transplantation? Transplantation 2004; 77(8): 1298-1301. PMID: 15114102.

78. Poitou C, Francois $\mathrm{H}$, Bellanne-Chantelot $\mathrm{C}$, Noel C, Jacquet $\mathrm{A}$, Clauin S, et al. Maturity onset diabetes of the young: clinical characteristics and outcome after kidney and pancreas transplantation in MODY3 and RCAD patients: a single center experience. Transpl Int 2012; 25(5): 564-572. PMID: 22432796. DOI: 10.1111/j.1432-2277.2012.01458.x.

79. Galler A, Stange T, Muller G, Näke A, Vogel C, Kapellen T, et al. Incidence of childhood diabetes in children aged less than 15 years and its clinical and metabolic characteristics at the time of diagnosis: data from the Childhood Diabetes Registry of Saxony, Germany. Horm Res Paediatr 2010; 74(4): 285-291. PMID: 20516654. DOI: 10.1159/000303141.

80. Pruhova S, Dusatkova P, Sumnik Z, Kolouskova S, Pedersen O, Hansen $T$, et al. Glucokinase diabetes in 103 families from a country-based study in the Czech Republic: geographically restricted distribution of two prevalent GCK mutations. Pediatr Diabetes 2010; 11(8): 529-535. PMID: 20337973. DOI: 10.1111/j.1399-5448.2010.00646.x.

81. Greeley SAW, Naylor RN, Cook LS, Tucker SE, Lipton RB, Philipson LH. Creation of the Web-Based University of Chicago Monogenic Diabetes Registry: using technology to facilitate longitudinal study of rare subtypes of diabetes. J Diabetes Sci Technol 2011; 5(4): 879-886. PMID: 2188022. DOI: $10.1177 / 193229681100500409$.

\section{Authors:}

Serghei Covanțev - Specialist, State University of Medicine and Pharmacy „Nicolae Testemițanu”, Chisinau, Republic of Moldova. 
Andrian Chiriac - MD, Pediatric endocrinologist, Department of Pediatric Endocrinology, Mother and Child Institute, Chisinau, Republic of Moldova. Ludmila Perciuleac - PhD, Department of Molecular Biology and Genetics, State University of Medicine and Pharmacy "Nicolae Testemițanu”, Chisinau, Republic of Moldova.

Vladlena Zozina - MPharm, Independent researcher, Chisinau, Republic of Moldova. 